J-SANAK: Jurnal Kajian Anak

(p-ISSN: 2686-5343 |e-ISSN: 2715-7989)

Vol. (1) (2), (Januari - Juni) (2019), (Halaman)(15-34)

DOI: https://doi.org/10.24127/j-sanak.v1i02.190

\title{
ANALISIS HUKUM KAUSALITAS TERHADAP PERILAKU ANAK USIA DINI
}

\author{
Wahyu Purwasih \\ IAIN Surakarta \\ wahyualfia@gmail.com
}

\begin{abstract}
ABSTRAK
Tulisan ini menyajikan tentang Kausalitas, Pemilihan Jodoh, Perekayasaan Genetika, dan Pengaruh Kekuatan Akidah Terhadap Perilaku Anak. Setiap perilaku yang dihasilkan oleh anak tidak terlepas dari sebab-sebab yang melatarbelakanginya, yang disebut dengan kausalitas. Pendidikan untuk anak sejatinya sudah dimulai ketika seseorang menentukan calon pendamping hidup. Seorang laki-laki berkewajiban memilih calon ibu yang baik untuk anak-anaknya kelak. Begitu pula seorang wanita, harus memilih calon imam yang dapat membimbingnya dalam urusan dunia dan akhirat. Terdapat beberapa hal yang harus dipertimbangkan dalam memilih pasangan hidup, seperti agama dan akhlak, kesehatan jasmani maupun rohani, dan jauh dari hubungan kekerabatan. Karena terdapat beberapa sifat yang diturunkan dari orangtua kepada anak. Selain berbagai faktor genetik yang dapat mempengaruhi pendidikan anak. Juga terdapat faktor lingkungan yang sangat berperan aktif dalam mendidik anak. Anak-anak yang dilahirkan dari lingkungan keluarga, masyarakat maupun sekolah yang memiliki akidah kuat, cenderung juga memiliki akidah yang kuat.
\end{abstract}

Kata Kunci : Kausalitas, Genetik, Anak Usia Dini

Received 05-04-2020; Received in revised form 30-05-2020; Accepted 31-05-2020

\begin{abstract}
This paper presents the Causality, the Choice of Mate, Genetic Engineering, and the Effect of the Strength of the Aqeedah on Child Behavior. Every behavior produced by a child is inseparable from the underlying causes, which is called causality. Education for children has actually begun when someone determines the prospective life companion. A man is obliged to choose a good future mother for his children. Likewise, a woman must choose a prospective priest who can guide her in world affairs and the hereafter. There are several things that must be considered in choosing a life partner, such as religion and morals, physical and spiritual health, and far from kinship. Because there are several traits that are passed down from parents to children. In addition to various genetic factors that can affect children's education. There are also environmental factors that play an active role in educating children. Children born from family environments,
\end{abstract}


J-SANAK: Jurnal Kajian Anak

(p-ISSN: 2686-5343 |e-ISSN: 2715-7989)

Vol. (1) (2), (Januari - Juni) (2019), (Halaman)(15-34)

DOI: https://doi.org/10.24127/j-sanak.v1i02.190

communities and schools that have strong faith, tend to also have strong faith. Keywords: Causality, Genetic, Early Child

\section{A. PENDAHULUAN}

Usia dini merupakan usia golden age. Semua aspek perkembangan anak berkembang sangat pesat pada usia ini. oleh karena itu, pada usia ini sangat penting untuk ditanamkan pondasi-pondasi pendidikan Islam sebelum anak mendapatkan pendidikan ilmu pengetahuan. Adapun pondasi pendidikan Islam yang harus ditanamkan pertama kali pada anak adalah pendidikan akidah dan ibadah. Sejatinya pendidikan anak usia dini sudah dimulai sejak pemilihan calon suami atau calon istri. Semakin tinggi jenjang pendidikan orang tua, semakin bagus persepsi orang tua mengenai pendidikan TK (Pratiwi et al., 2018)

Pendidikan anak usia dini merupakan upaya memberikan pendidikan kepada anak mulai usia 0-6 tahun. Islam menganjurkan memberikan pendidikan kepada anak bahkan sejak memilih pasangan. Orang tua memiliki peran utama dalam memberikan pendidikan kepada anak. Sehingga wajib bagi calon ayah untuk mencari ibu yang baik bagi anak-anaknya kelak. Karena perilaku anak dibentuk oleh pendidikan dari lingkungan sekitar, khususnya keluarga, dipengaruhi oleh faktor genetik, serta penanaman akidah sejak kecil.

Berdasar uraian tentang latar belakang dan problematika sebagaimana dikemukakan di atas sebagai indikator penelitian ini diharapkan dapat muncul jawaban terhadapa pertanyaan, sebagai berikut:

1. Bagaimana hukum kausalitas bekerja dalam membentuk perilaku anak?

2. Apa saja yang termasuk ke dalam ruang lingkup hukum kausalitas?

\section{B. METODOLOGI}

Adapun metode yang digunakan dalam penelitian ini ialah penelitian kepustakaan (library research). Penelitian kepustakaan ialah penelitian yang memperoleh data atau bahan-bahannya yang diperlukan dari perpustakaan baik berupa buku, ensklopedi, kamus, jurnal, dokumen, majalah dan sebagainya. Sistem pelayanan perpustakaan biasanya ada dua macam, yaitu, sistem tertutup dan sistem terbuka. Adapun perpustakaan yang dilibatkan dalam hal ini ialah perpustakaan dengan sistem terbuka, yang mana peminjam dapat langsung mencari dan memilih buku atau sumber yang dibutuhkannya kedalam ruangan buku (Harahap, 2014). 
J-SANAK: Jurnal Kajian Anak

(p-ISSN: 2686-5343 le-ISSN: 2715-7989)

Vol. (1) (2), (Januari - Juni) (2019), (Halaman)(15-34)

DOI: https://doi.org/10.24127/j-sanak.v1i02.190

\section{HASIL DAN PEMBAHASAN}

\section{Prinsip Kausalitas}

Setiap peristiwa yang terjadi dan perilaku yang dilakukan oleh seseorang pasti memiliki sebab-sebab. Adapun penjelasan tentang kausalitas akan diuraikan sebagai berikut:

Kausalitas menurut Kamus Besar Bahasa Indonesia, Kausalitas berarti perihal sebab akibat (Pustaka, 2002). Cambell yang dikutip oleh (Hastjarjo, 2011) memaparkan bahwa suatu peristiwa yang terjadi disebabkan oleh kondisi yang cukup, bukan kondisi yang perlu. Pernyataan ini dapat dipahami bahwa penyebab dari suatu peristiwa tidak semata-mata dari satu penyebab yang mutlak. Penyebab tersebut pasti disertai dengan penyebab-penyebab yang lain. Misalkan dalam dunia pendidikan, anak yang kurang dalam bidang akademik tidak bisa dikatakan itu mutlak karena guru. Akan tetapi bisa juga disebabkan karena kurangnya perhatian dari orangtua, lingkungan masyarakat, kesehatan. Masing-masing penyebab tersebut juga belum cukup dikatakan sebagai penyebab kurangnya akademik siswa. Karena guru yang dianggap menjadi penyebab kurangnya akademik siswa haruslah guru yang tidak menguasai materi, guru tidak mengetahui psikologi anak, guru tidak menggunakan metode belajar yang tepat, dan sebagainya.

(Salehnur, 2014) mengutip pendapat Al Ghazali yang menyatakan bahwa suatu penyebab yang diyakini sebagai akibat dari kebiasaan tidaklah bersifat pasti. Misalnya hubungan antara hilangnya rasa haus dengan minum, merasakan kenyang dengan makan, kebakaran karena api dan sebagainya. Al Ghazali menegasikan hal ini, karena Tuhan dapat menciptakan rasa kenyang tanpa makan, menghilangkan dahaga tanpa minum, dan sebagainya. Segala sesuatu dapat terjadi bila Allah mengizinkan, termasuk pada sesuatu yang mustahil.

Ibn Rusyd dalam (Salehnur, 2014) menyanggah pendapat Al Ghazali ini. Menurutnya, hukum kausalitas itu bersifat pasti. Seperti halnya api yang menyebabkan kebakaran. Beliau berpendapat bahwa alasan mengapa api tidak bisa membakar Nabi Ibrahim bukan karena Allah mengubah sifat api. Akan tetapi karena Allah memberi suatu penghalang sehingga sifat api yang panas tidak dirasakan oleh tubuh Nabi Ibrahim.

Beberapa pendapat di atas dapat ditarik kesimpulan bahwa suatu peristiwa atau perilaku dapat terjadi dikarenakan berbagai faktor yang dinamakan dengan prinsip kausalitas. Begitu pula perilaku yang dihasilkan oleh anak. Setiap perilaku anak baik itu positif maupun negatif pasti terdapat berbagai faktor yang melatarbelakanginya. Oleh karena itu, sebagai pendidik hendaknya memahami 
J-SANAK: Jurnal Kajian Anak

(p-ISSN: 2686-5343 |e-ISSN: 2715-7989)

Vol. (1) (2), (Januari - Juni) (2019), (Halaman)(15-34)

DOI: https://doi.org/10.24127/j-sanak.v1i02.190

psikologi anak dan mencari tahu penyebab dari perilaku anak sebelum mengambil tindakan.

\section{Prinsip Memilih Jodoh}

Membangun dan membina keluarga sakinah, mawaddah warrahmah merupakan dambaan semua orang. Seorang calon bapak tidaklah cukup untuk menjaga benteng akidah Islam. Diperlukan calon ibu muslim untuk bersama-sama bersinergi mewujudkannya. Adapun prinsip pemilihan jodoh secara umum antara lain:

a. Memilih calon istri atau suami yang sholeh

Islam menganjurkan untuk memilih calon istri atau suami yang soleh dengan menganalogikan bahwa benih baik dan sehat yang terepresentasikan dalam sperma laki-laki, dan lahan yang subur dan sehat terepresentasikan dalam ovum perempuan biasanya akan melahirkan tanaman yang sehat. Pertimbangannya, istri yang solehah lebih dekat dengan kemuliaan, keutamaan, perilaku yang baik, dan akhlak yang luhur. Rasulullah memberikan tuntutan kepada laki-laki yang ingin menikah supaya memilih calon istri yang baik agamanya (Al-Albani et al., 2002). Sebagaimana sabda Nabi:

Wanita dinikahi karena empat sebab: karena hartanya, keturunannya, kecantikannya dan agamanya. Maka pilihlah wanita yang berpegang kepada agama agar kamu selamat. (Riwayat Bukhari Muslim dari Abu Hurairah).

Hadits di atas menjelaskan bahwa agama merupakan pertimbangan pertama dalam memilih calon pendamping hidup. Seorang laki-laki yang memilih wanita karena baik agamanya, dijamin akan mendapatkan keselamatan. Hal ini memang benar, karena wanita yang baik agamanya akan senantiasa patuh kepada suami. Sehingga sang suami juga semangat dalam mencari nafkah. Selain itu, wanita sholehah juga akan memberikan keturunan yang sholeh dan sholehah juga.

Rasulullah menganjurkan untuk menikahi wanita berdasarkan empat pertimbangan. Pertimbangan pertama yaitu agama, seperti yang sudah dijelaskan diatas. Wanita yang berharta juga menjadi salah satu pertimbangan dalam memilih jodoh. Diharapkan dengan harta yang dimiliki dapat membantu sang suami dalam menyebarluaskan Islam dan memperkuat kaum muslimin seperti usaha keras yang dilakukan ibunda Khadjijah bersama Rasul. Pertimbangan yang selanjutnya yaitu berdasarkan nasabnya. Wanita yang berasal dari keturunan baik-baik dan taat beragama, cenderung juga memiliki sifat yang sama. Yang nantinya juga akan melahirkan putra-putri sholeh sholehah. Sedangkan pertimbangan yang terakhir 
J-SANAK: Jurnal Kajian Anak

(p-ISSN: 2686-5343 |e-ISSN: 2715-7989)

Vol. (1) (2), (Januari - Juni) (2019), (Halaman)(15-34)

DOI: https://doi.org/10.24127/j-sanak.v1i02.190

yaitu karena kecantikannya. Sifat bawaan seorang laki-laki adalah menyukai wanita cantik. Kecantikan disini diartikan sebagai kecantikan dari dalam atau inner beauty. Karena definisi cantik itu relatif, tidak sama antar satu orang dengan orang yang lain. Oleh karena itu laki-laki dianjurkan menikahi wanita yang sejuk dipandang.

KH. Maimun Zubair memberi nasehat kepada para pemuda bahwa dalam memilih istri hendaknya jangan memilih istri yang terlalu mengerti dunia. Karena kesholehan anaknya kelak tergantung seberapa sholehah ibunya (Musthafa, 2004). (Hafizh, 2010) juga menguatkan bahwa memilih istri yang baik merupakan hak anak atas bapaknya. Hal ini dikutip dari pernyataan Umar bin Khaththab: "Hak yang pertama untuk anak adalah dipilihkan baginya seorang ibu sebelum dia dilahirkan; yang cantik, mulia, taat beragama, terhormat, cerdas, berakhlak terpuji, teruji kecerdasannya, dan kepatuhannya kepada sang suami”.

Pendapat para ulama di atas dapat dipahami bahwa memilih wanita yang akan dijadikan sorang istri merupakan perkara penting. Keputusan memilih ini akan menjadi penentu kehidupan setelah menikah. Selain itu, menikah juga bukan hanya sebagai penyalur hasrat. Tetapi juga kehidupan jangka panjang. Maka dari itu sangat penting untuk mengutamakan agama terlebih dahulu dari pada alasan yang lain. Istri yang sholehah akan mengahsilkan keturunan yang sholehah pula. Yang dapat menjadi tabungan kelak di akhirat. Begitu pula pada laki-laki, Setiap perempuan hendaklah memilih calon suami berdasarkan agama dan akhlaknya. Laki-laki yang sholeh konsisten memegang teguh agamanya, dan berkomitmen pada akhlak yang luhur (Al-Albani et al., 2002). Sebagaimana sabda Rasulullah:

Apabila datang kepadamu seorang yang kamu senangi agama dan akhlaknya, maka kawinkanlah dia dengan anak perempuanmu, jika tidak, niscaya akan mendatangkan fitnah di bumi ini dan akan menimbulkan kerusakan yang mengerikan. (Riwayat Tirmidzi, Ibnu Majah dan Hakim dari Abu Hurairah).

Laki-laki diibaratkan sebagai seorang nahkoda yang harus mengarungi samudra kehidupan bersama istri. Dalam memilih nahkoda haruslah yang berpengalaman, pandai membuat strategi ketika terjadi badai, dan sama-sama memiliki tujuan yang jelas. Maka dari itu, bila datang seorang laki-laki yang baik agama dan akhlaknya ingin melamar, wali perempuan dilarang untuk menolaknya. Begitu pula seorang laki-laki diwajibkan memiliki bekal agama yang kuat sebelum memutuskan untuk menikahi seorang wanita. Memiliki kemampuan untuk mengajarkannya dan selalu menjaga sikap dan perbuatan. Karena kelak ia 
J-SANAK: Jurnal Kajian Anak

(p-ISSN: 2686-5343 |e-ISSN: 2715-7989)

Vol. (1) (2), (Januari - Juni) (2019), (Halaman)(15-34)

DOI: https://doi.org/10.24127/j-sanak.v1i02.190

akan menjadi imam bagi sang istri dan anak-anaknya. Dan bersiap menghadapi suka-duka kehidupan bersama.

b. Pemilihan atas dasar kesehatan rokhani dan jasmani

Kesehatan calon suami atau istri juga harus menjadi pertimbangan sebelum memutuskan untuk menikah. Karena kesehatan ibu dan ayah sangat berpengaruh pada kesehatan alat reproduksi, baik itu kesehatan fisik maupun kesehatan rokhani. Misalkan saja seorang calon suami yang depresi akan berpengaruh pada kualitas sperma yang dihasilkan. Begitu pula seorang ibu hamil yang depresi, akan sangat berpengaruh pada psikologi anak yang dikandung. Oleh karena itu, sebelum melaksanakan pernikahan kedua calon mempelai harus menjalani tes kesehatan. Tes kesehatan pra nikah merupakan usaha menjaga keturunan dan mencegah penularan penyakit (Aprilian, 2017).

Selain harus memperhatikan kesehatan jasmani, dalam memilih pasangan juga harus memperhatikan kesehatan rohani atau kesehatan psikologi. Penelitian menunjukkan bahwa semakin matang usia suami istri saat menikah maka akan semakin matang kesiapannya menjadi orang tua dan semakin baik pula stimulasi psikososial yang diberikan untuk anak. Hal ini meningkatkan peluang perkembangan sosial anak untuk menjadi lebih baik (Setyowati et al., 2017).

\section{Menghindari perkawinan dengan kerabat dekat}

Memilih calon suami atau istri hendaklah yang tidak ada kaitannya dengan nasab dan keluarga. Tujuannya adalah untuk menjaga kesehatan dan kecerdasan anak (Syobromalisi, 2016). (Hermanto, 2017) menguatkan bahwa larangan pernikahan menurut fikih dibagi menjadi dua, yaitu larangan abadi dan larangan sementara. Pertama, larangan abadi adalah dikarenakan terdapat hubungan nasab, sepersusuan, kerabat semenda, dan sumpah li'an. Adapun kerabat nasab yang dilarang untuk dinikahi yaitu ibu kandung, anak perempuan kandung, cucu perempuan, saudara perempuan, bibi, keponakan. Sedangkan kerabat semenda yang dilarang untuk dinikahi adalah mertua perempuan, anak tiri, ibu tiri, dan menantu. Kedua, larangan sementara disebabkan karena beberapa hal yaitu karena menikahi perempuan lebih dari empat, menikahi dua perempuan kakak beradik dalam waktu yang sama, dalam keadaan ihram, masih dalam waktu iddah, talaq tiga, kafir, dan masih menjadi istri orang lain.

Larangan Allah untuk menikah dengan kerabat dekat dikarenakan secara genetika hubungan darah lebih memungkinkan menghasilkan anak yang menderita penyakit-penyakit yang diwariskan secara resesif. Setiap manusia Copyright $\odot$ 2020, Universitas Muhammadiyah Metro| 20 
J-SANAK: Jurnal Kajian Anak

(p-ISSN: 2686-5343 |e-ISSN: 2715-7989)

Vol. (1) (2), (Januari - Juni) (2019), (Halaman)(15-34)

DOI: https://doi.org/10.24127/j-sanak.v1i02.190

memiliki DNA yang membawa sifat resesif dan dominan, semakin dekat kekerabatan seseorang maka semakin sama pula komposisi DNA yang dimiliki. Bila sesama kerabat dekat memaksakan untuk menikah, akan terjadi perpaduan antara DNA yang resesif. Yang mengakibatkan DNA tersebut menjadi dominan pada keturunan yang selanjutnya. Bambang (Supriyadi \& Drajad, n.d.) menambahkan bahwa gangguan mental juga merupakan penyakit keturunan yang disebabkan oleh gen resesif. Dari pendapat ini dapat dipahami bahwa salah satu kemungkinan dari pernikahan dengan kerabat dekat adalah dapat menurunkan anak yang memiliki gangguan mental.

(Yusdiawati, 2018) menyampaikan bahwa resiko penyakit yang menjadi dampak perkawinan sepupu, bukanlah dampak negatif yang mutlak pada semua pasangan sepupu. Bila dikaitkan dengan larangan menikahi kerabat nasab, saudara sepupu tidak termasuk di dalamnya. Sehingga dapat disimpulkan bahwa kerabat yang paling dekat yang boleh dinikahi adalah saudara sepupu.

Selanjutnya (Arisman, 2018) meneliti tentang larangan perkawinan sesuku. Hasil penelitian menyimpulkan bahwa perkawinan sesuku hukumnya boleh, karena larangan perkawinan sesuku tidak termasuk ke dalam kategori daruriyat, tetapi hanya masuk kategori hajiyyat. Karena dibutuhkan masyarakat matrilinial untuk mempermudah mencapai kesejahteraan rumah tangga. Pernikahan dengan seseorang yang tidak memiliki hubungan kerabat juga bertujuan untuk memperluas hubungan. Dengan demikian, benteng pertahanan Islam semakin luas dan kokoh.

c. Memilih perempuan yang masih perawan

Memilih perempuan yang masih perawan untuk dinikahi merupakan anjuran Rasulullah. Hal ini dikarenakan perempuan yang masih perawan memiliki rasa cinta yang lebih besar kepada keluarganya (Al-Albani et al., 2002). Sebagaimana sabda Rasul:

Hendaknya kalian menikahi gadis perawan, karena mereka lebih bagus pergaulannya, lebih subur rahimnya dan lebih bisa menerima kekurangan (HR. Bukhori Muslim).

Hadits di atas dapat dipahami bahwa perempuan yang masih perawan menjadi prioritas dan patut dipertimbangkan untuk dijadikan pendamping. Hal ini dikarenakan perempuan yang masih perawan memiliki alat reproduksi yang lebih subur dari pada yang sudah tidak perawan. Sehingga dapat menghasilkan 
J-SANAK: Jurnal Kajian Anak

(p-ISSN: 2686-5343 |e-ISSN: 2715-7989)

Vol. (1) (2), (Januari - Juni) (2019), (Halaman)(15-34)

DOI: https://doi.org/10.24127/j-sanak.v1i02.190

keturunan yang lebih berkualitas pula. Selain itu, pergaulannya juga masih terjaga dari obrolan-obrolan tetangga yang kurang baik. Sehingga diharapkan dapat menerima kekurangan sang suami dengan lebih baik.

d. Memilih perempuan yang bisa melahirkan anak

Anak merupakan tabungan akhirat bagi setiap orangtua. Oleh karena itu, Islam sangat menekankan para calon imam untuk memilih calon istri yang dapat memberikan keturunan (Al-Albani et al., 2002). Sebagaimana sabda Rasul:

Seorang laki-laki datang kepada Rasulullah, lalu berkata: "Wahai Rasulullah, saya telah mendapatkan seorang perempuan dari keturunan terhormat, kedudukan sosialnya tinggi, dan berharta, namun mandul. Bolehkah saya mengawininya?”. Beliau melarangnya. Orang itu datang kedua kalinya dan berkata kepada beliau seperti semula. Ia datang untuk ketiga kalinya, kemudian Rasulullah bersabda kepadanya: "Kawinilah oleh kalian wanita yang rasa cintanya besar dan subur, karena kelak aku akan membanggakan kalian dihadapan umat-umat lain." (HR. Abu Dawud, Nasa'i dan Hakim).

Hadits di atas menerangkan bahwa hendaknya laki-laki memilih wanita yang subur untuk dinikahi, yaitu wanita yang dapat melahirkan anak. Karena tujuan pernikahan sesungguhnya adalah memperbanyak keturunan. Sehingga kekuatan umat Islam juga semakin besar. Tentunya juga dengan memberikan pendidikan yang baik dan perhatian yang cukup. Akan menjadi percuma bila mempunyai banyak anak, akan tetapi pendidikannya terbengkalai. Rasul menghimbau untuk memiliki banyak anak dan memberikan pendidikan yang berkualitas. Karena anak-anak yang sholeh akan menjadi kebanggaan di dunia dan tabungan berharga di akhirat.

e. Menghindari wanita yang memiliki sifat buruk

Di kalangan orang Arab terdapat beberapa sifat wanita yang tidak terpuji, sehingga tidak dianjurkan untuk memilihnya sebagai seorang istri. Adapun sifatsifat tersebut antara lain:

1) Annanah. Yaitu wanita yang senantiasa mengeluh. Dalam membangun rumah tangga banyak sekali cobaan yang harus dihadapi oleh suami dan istri. Memerlukan kekompakan antara keduanya dalam menyelesaikan suatu masalah. Oleh karena itu, Islam tidak menganjurkan untuk menikahi wanita 
J-SANAK: Jurnal Kajian Anak

(p-ISSN: 2686-5343 le-ISSN: 2715-7989)

Vol. (1) (2), (Januari - Juni) (2019), (Halaman)(15-34)

DOI: https://doi.org/10.24127/j-sanak.v1i02.190

yang suka mengeluh karena wanita yang seperti ini sangat rapuh. Dan dikhawatirkan hubungan pernikahan akan rusak.

2) Mannanah. Yaitu wanita yang suka mengungkit perbuatannya terhadap suami. Wanita yang suka mengungkit perbuatannya kepada suami menandakan bahwa ia tidak ikhlas dalam menjalankan sesuatu.

3) Hannanah. Yaitu wanita yang berselingkuh. Wanita yang berselingkuh tidak dianjurkan untuk dinikahi. Karena ia tidak taat kepada suami.

4) Haddaqah. Yaitu wanita yang pintar merayu ketika menginginkan sesuatu sehingga suami terpaksa memenuhinya. Wanita yang seperti ini harus dihindari. Karena ia dapat membuat sang suami menghalalkan segala cara demi memenuhi keinginannya.

5) Barraqah. Yaitu wanita yang selalu sibuk berhias diri tanpa memperhatikan tugasnya sebagai seorang istri dan ibu. Para pemuda hendaklah tidak memilih wanita yang seperti ini untuk dinikahi. Karena mereka tidak mau menjalani kodratnya sebagai seorang istri dan ibu.

6) Syaddaqah. Yaitu wanita yang terlalu banyak bicara. Para pemuda hendaknya menghindari memilih wanita yang terlalu banyak bicara (Daudin, 1996).

Beberapa penjelasan di atas menyiratkan bahwa pertimbangan pemilihan calon istri lebih banyak dari pada kriteria pemilihan calon suami. Hal ini menunjukkan bahwa Islam menyadari seorang wanita berperan sangat besar bagi kelangsungan mahligai rumah tangganya. Oleh karena itu, sebelum memutuskan untuk menuju ke jenjang pernikahan, hendaklah para pemuda mencari tahu informasi mengenai calon suami atau calon istri. Kesalahan yang sering terjadi di masyarakat adalah terburu-buru untuk menikah sedang ia belum mengetahui betul kepribadian sang calon. Dalam mencari informasi ini dapat dilakukan dengan melihat siapa teman dekatnya, menanyakan sifat-sifat calon suami atau istri melalui tetangganya, mencari tahu informasi melalui gurunya, dan memohon petunjuk kepada Allah dengan sholat istikhoroh.

Allah juga telah berfirman dalam Al Quran surat An Nur ayat 26:

Wanita-wanita yang keji adalah untuk laki-laki yang keji, dan laki-laki yang keji adalah buat wanita-wanita yang keji (pula), dan wanita-wanita yang baik adalah untuk laki-laki yang baik dan laki- laki yang baik adalah untuk wanita-wanita yang baik (pula). mereka (yang dituduh) itu bersih dari apa 
J-SANAK: Jurnal Kajian Anak

(p-ISSN: 2686-5343 |e-ISSN: 2715-7989)

Vol. (1) (2), (Januari - Juni) (2019), (Halaman)(15-34)

DOI: https://doi.org/10.24127/j-sanak.v1i02.190

yang dituduhkan oleh mereka (yang menuduh itu). bagi mereka ampunan dan rezki yang mulia (surga)(Departemen Agama, 2005).

Ayat di atas menjelaskan bahwa perempuan yang tidak baik akhlaknya, kelak juga akan mendapatkan jodoh seorang laki-laki yang akhlaknya tidak baik juga. Sedangkan perempuan yang baik akhlaknya, kelak akan mendapatkan jodoh yang baik pula akhlaknya. Dapat dipahami bahwa Allah memang telah menentukan jodoh setiap manusia, bahkan semenjak ia lahir. Akan tetapi kualitas jodoh itu ditentukan oleh seberapa kuat usaha seseorang. Allah telah menjamin kualitas jodoh seseorang berdasarkan kualitas dirinya. Oleh karena itu, sebagai pemuda hendaklah menjaga pandangan, senantiasa memperbaiki diri dan berusaha mendekatkan diri kepada Allah.

\section{Perekayasaan Genetika}

Setiap anak yang terlahir di dunia merupakan hasil perpaduan antara gen ayah dan ibu. Islam sangat menganjurkan untuk memilih calon pendamping yang baik budi pekertinya. Karena lahan yang subur dan biji yang berkualitas bagus akan menghasilkan tanaman yang baik pula.

Ketika sperma dan ovum menyatu saat pembuahan, mereka memproduksi 23 zigot dengan 46 kromosom, 23 dari gen ibu dan 23 dari gen ayah. Sebuah zigot kemudian melakukan pembelahan diri secara berulang-ulang hingga terbentuklah komposisi tubuh lengkap yang memiliki struktur DNA yang sama satu sama lain. Aksi genetik ini diatur dalam level hormonal yang dipengaruhi oleh kondisi lingkungan seperti nutrisi dan stress. Oleh karena itu, sifat turunan dan lingkungan saling berhubungan sejak awal (Allingham-Hawkins, 2008). Dalam istilah Kamus Besar Bahasa Indonesia (Pustaka, 2002) juga dikuatkan bahwa ciri-ciri lahiriah organisme yang dihasilkan karena interaksi antara ciri-ciri keturunan dan lingkungan disebut dengan fenotip.

Memiliki keturunan merupakan keinginan bagi setiap pasangan yang sudah menikah. Akan tetapi beberapa orangtua mengalami ketidak suburan. Yang mengharuskan mereka untuk melakukan tindakan medis demi mendapatkan keturunan. Tindakan ini biasa disebut dengan perekayasaan genetika. Islam tidak mengharamkan pembuahan buatan atau bayi tabung dengan catatan sperma dan ovum yang direkayasa berasal dari suami istri yang sudah menikah. Pelaksanaan program bayi tabung di Indonesia diatur dalam Undang-undang Nomor 36 Tahun 2009 tentang kesehatan. Di dalamnya diatur bagaimana syarat dan prosedur yang 
J-SANAK: Jurnal Kajian Anak

(p-ISSN: 2686-5343 le-ISSN: 2715-7989)

Vol. (1) (2), (Januari - Juni) (2019), (Halaman)(15-34)

DOI: https://doi.org/10.24127/j-sanak.v1i02.190

harus dipenuhi selama mengikuti program sehingga tidak melanggar etika di masyarakat dan agama (Isnawan, 2019) Adapun beberapa metode pembuahan buatan antara lain:

a) Sperma laki-laki yang dibuahkan dengan sel telur yang bukan istrinya. Lalu sel yang telah dibuahi ditanam di rahim sang istri. Hal ini dilakukan karena indung telur mengalami gangguan penyakit.

b) Pembuahan antara sel telur istri dengan sel sperma laki-laki yang bukan suami. Lalu sel telur yang telah dibuahi, ditanam di rahimnya. Hal ini dilakukan karena sel sperma suami tidak normal.

c) Pembuahan dilakukan di luar antara sel sperma suami dan istri, lalu hasilnya ditanam di rahim wanita yang sengaja di sewa. Hal ini dikarenakan rahim sang istri mengalami gangguan.

d) Pembuahan luar antara sperma laki-laki dan sel telur perempuan yang bukan suami istri. Lalu hasilnya ditanam di rahim istri karena dia dan suaminya mandul.

e) Pembuahan luar antara sperma laki-laki dan sel telur istri, lalu di tanam di rahim istri yang kedua karena istri yang pertama mempunyai penyakit.

f) Sel sperma laki-laki dan sel telur istri sama-sama diambil lalu dilakukan pembuahan di luar rahim. Setelah itu ditanam di rahim sang istri karena istri mengalami penyakit.

g) Sperma laki-laki diambil baru kemudian diletakkan disaluran telur istrinya. Dikarenakan adanya gangguan yang menghalangi sampainya sel sperma ke sel telur (Alrabeeah et al., 2015).

Cara yang pertama sampai ke empat tidak diperbolehkan oleh agama. Karena sel sperma dan sel telur sama-sama bukan dari suami istri yang menikah. Walaupun telah terjadi persetujuan antara suami istri dan pada akhirnya ditanam di rahim sang istri, akan tetapi tetap digolongkan dalam berzina (Saiful, 2016). Sedangkan cara yang ketiga tetap tidak perbolehkan walaupun itu sama-sama dari sperma dan ovum suami istri. Karena menyewa rahim perempuan lain memiliki resiko yang sangat tinggi dan berkaitan dengan nyawa seseorang. Cara yang kelima sampai ketujuh diperbolehkan oleh agama. Karena sel sperma dan telur sama-sama dari suami istri yang menikah. Akan tetapi pada cara nomor lima, ibu biologis dinisbatkan pada istri yang kedua. Yang telah susah payah mengandung selama 9 bulan. 
J-SANAK: Jurnal Kajian Anak

(p-ISSN: 2686-5343 |e-ISSN: 2715-7989)

Vol. (1) (2), (Januari - Juni) (2019), (Halaman)(15-34)

DOI: https://doi.org/10.24127/j-sanak.v1i02.190

Terjadi perbedaan pendapat mengenai penyewaan rahim. Dalam konsep KUH Perdata, anak yang dilahirkan melalui proses bayi tabung dengan menggunakan sperma donor berkedudukan sebagai anak sah apabila mendapat pengakuan (Pasan 280 KUH Perdata), kemudian anak yang dilahirkan mellaui proses bayi tabung dengan menggunakan rahim sewaan berkedudukan sebagai anak angkat (Pasal 8 Stb. 1917/129) (Zahrowati, 2018). (Arikhman, 2016) membantah bahwa Surrogate mother (menyewa rahim) tidak diizinkan dan tidak bisa diterapkan di indonesia karena tidak ada payung hukum yang utuh serta berbenturan dengan aspek sosial, tradisi, dan keyakinan masyarakat Indonesia. Hal ini didukung oleh (Halimah, 2018) yang berpendapat bahwa tindakan medik surrogate mother dikategorikan sebagai perbuatan zina dan bertentangan dengan kode etik dokter.

(Wiryantha et al., 2017) juga berpendapat bahwa perjanjian surogasi tidak sah di mata hukum positif Indonesia, alasan yang kedua adalah secara sosial anak yang dilahirkan tidak memiliki status yang jelas di masyarakat tempat ibu pengganti. Sedangkan (Idris, 2019) berpendapat bahwa bayi tabung diperbolehkan asalkan sprema yang diambil merupakan dari suami istri yang sah dan ditanam dalam rahim istri (bukan rahim orang lain), selain itu dokter yang menangani harus perempuan.

Dapat disimpulkan bahwa menyewa rahim untuk kepentingan program bayi tabung sangat tidak sesuai dengan norma agama dan aspek sosial masyarakat Indonesia. Karena ibu pengganti menanggung resiko yang sangat besar, baik nyawa, ekonomi, sosial, maupun psikologis.

Bayi yang dilahirkan melalui pembuahan alami maupun perekayasaan genetika, memiliki sifat-sifat yang diturunkan dari kedua orangtuanya. (Mussen \& alih bahasa Tjndarasa, 1988) memaparkan bahwa terdapat beberapa faktor bawaan yang diwarisi dari orangtua biologis, antara lain:

a) Ciri fisik. Ciri fisik merupakan hasil pewarisan gen yang paling mudah dilihat. Seperti warna mata, pigmentasi kulit, dan kekeritingan rambut. Pewarisan ciri fisik sangat tergantung dengan dominan ataukah resesif gen tersebut. Misalkan gen untuk warna mata. Gen untuk warna mata coklat lebih dominan dibandingkan dengan gen untuk warna mata biru. Sehingga jika seorang wanita bermata biru dan laki-laki bermata coklat, kemungkinan yang terjadi adalah minimal dari separuh anak mereka akan memiliki warna mata coklat. 
J-SANAK: Jurnal Kajian Anak (p-ISSN: 2686-5343 |e-ISSN: 2715-7989)

Vol. (1) (2), (Januari - Juni) (2019), (Halaman)(15-34)

DOI: https://doi.org/10.24127/j-sanak.v1i02.190

b) Kecerdasan. Kecerdasan merupakan salah satu aspek yang diwariskan oleh orangtua. Kecerdasan yang dimaksud yaitu kecerdasan IQ. Beberapa penelitian menunjukkan bahwa kecerdasan orangtua diturunkan kepada anak. Kecerdasan dari orangtua ini lebih pada kecerdasan ibu yang diturunkan. Karena kecerdasan ayah berada pada ekor sperma. Dan ekor tersebut tidak ikut masuk ke dalam sel telur pada saat pembuahan. Pada kasus lain, kecerdasan anak adopsi pada dasarnya merupakan turunan dari orangtua biologis. Jika sering ditemui anak yang kecerdasannya sama dengan orangtua angkat, maka itu merupakan pengaruh lingkungan. Sekali lagi, kecerdasan yang diturunkan dari ibu ini hanya sebatas genetika saja. Untuk perkembangan kecerdasan selanjutnya sangat dipengaruhi oleh lingkungan yang membesarkan anak.

c) Keterbelakangan mental. Terdapat beberapa keterbelakangan mental yang salah satu faktornya karena keturunan. Keterbelakangan mnetal ini diwariskan oleh orangtua yang memiliki gen dominan. Sindrom down merupakan bentuk keterbelakangan mental turunan karena terdapat tambahan 1 kromosom pada pasangan ke 21. Anak yang menderita sindrom down kerap disebut dengan wajah seribu, karena bentuk wajah mereka sama. Selain itu, sindrom klinefelter juga merupakan kelainan bawaan sebagai akibat kelebihan kromosom X pada laki-laki. Sehingga anak yang menderita sindrom ini akan steril. Serta karakteristik maskulin mereka gagal berkembang, seperti terjadi pembesaran buah dada. Kedua sindrom ini tidak selalu disebabkan karena pewarisan gen dari orangtua. Beberapa hal nongenetik juga dapat menjadi pemicu kelainan ini, seperti radiasi, obatobatan, penyakit, dan sebagainya.

d) Gangguan mental. Schizophrenia dan depresi merupakan dua gangguan mental yang dapat diwariskan dari orangtua kepada anak. Schizophrenia merupakan gangguan berpikir secara logis dan reaksi emosi yang tidak tepat. Walaupun Schizophrenia dan depresi dapat diturunkan, akan tetapi anak yang berasal dari orang tua yang menderita Schizophrenia dan depresi tidak selalu menderita juga, mereka hanya berpotensi saja (Mussen \& alih bahasa Tjndarasa, 1988). Kemungkinan gangguan ini akan muncul bila ada faktor-faktor pemicu yang menyebabkannya. Dalam buku lain dikatakan bahwa autisme juga merupakan salah satu gangguan mental yang diturunkan dari orangtua. Autisme merupakan kelainan fungsi otak yang ditandai dengan lemahnya dalam berkomunikasi, menolak melakukan kontak mata, dan menunjukkan perilaku yang berulang. Anak yang menderita autisme ini 
J-SANAK: Jurnal Kajian Anak

(p-ISSN: 2686-5343 le-ISSN: 2715-7989)

Vol. (1) (2), (Januari - Juni) (2019), (Halaman)(15-34)

DOI: https://doi.org/10.24127/j-sanak.v1i02.190

dikategorikan sebagai anak berkebutuhan khusus. Bila autisme yang dideritanya parah, maka cukup diberi pendidikan kecakapan hidup dan menggali bakat serta minat anak.

e) Karakteristik kepribadian. Kepribadian seseorang juga dapat dipengaruhi oleh hereditas. Salah satu sifat kepribadian yang dibawa sejak lahir yaitu temperamen. (Allingham-Hawkins, 2008) menyatakan bahwa orangtua yang temperamen cenderung menurunkan sifat tersebut kepada anaknya.

Menurut Ashley Montagu yang dikutip oleh (Hasyim, 1991), menyatakan bahwa gangguan emosional pada ibu hamil dapat mempengaruhi perkembangan struktur maupun jiwa calon bayi. Hal ini dikarenakan perubahan-perubahan emosi pada ibu hamil menghasilkan perubahan-perubahan kimiawi dalam tubuh dapat menyebabkan janin menerima zat-zat kimia tertentu secara berlebihan sehingga menyebabkan gangguan pada pertumbuhan dan perkembangan janin. Dari uraian di atas dapat dipahami bahwa kebanyakan hasil penelitian menunjukkan sifat-sifat yang diturunkan oleh orangtua lebih kepada sifat psikis anak. Bila ditemui orangtua yang cacat fisik, maka anak yang dihasilkan belum tentu memiliki cacat fisik yang sama.

Selain itu, keturunan bukan satu-satunya faktor mutlak yang menjadi penyebab gangguan pada anak. Penelitian (Santy \& Irtanti, 2014) menunjukkan bahwa tempertantrum pada anak usia 2-4 tahun disebabkan karena pola asuh orang tua yang kurang baik, yaitu pola asuh permisif. (Kusramadhanty, 2019) juga menambahkan bahwa pengasuhan ayah akan memberikan pengaruh positif terhadap pengasuhan ibu dan temperamen anak. Beberapa penelitian di atas dapat dipahami bahwa kondisi lingkungan, keadaan mental orangtua, dan gaya hidup juga turut menjadi penyumbang gangguan pada anak. Oleh karena itu, seorang ibu yang hamil harus senantiasa merasa bahagia. Karena apapun yang dimakan dan dipikirkan akan membentuk karakter anaknya kelak.

\section{Pengaruh Kekuatan Akidah}

Dalam pendidikan anak usia dini, penanaman akidah harus menjadi perhatian besar yang harus diberikan pada anak bahkan sejak dalam kandungan. Kekuatan akidah menjadi pondasi dasar sebelum anak menerima pendidikan yang lainnya. Islam mengajarkan bahwa kesalehan kedua orangtua memiliki dampak yang sangat besar dalam jiwa anak. Hal ini dibuktikan dengan usaha kerasnya para ulama untuk mendapatkan anak yang shaleh. Seperti, Sahal at Tustari melakukan berbagai amal sholeh demi mendapatkan anak yang sholeh dan Sa'id bin 
J-SANAK: Jurnal Kajian Anak

(p-ISSN: 2686-5343 le-ISSN: 2715-7989)

Vol. (1) (2), (Januari - Juni) (2019), (Halaman)(15-34)

DOI: https://doi.org/10.24127/j-sanak.v1i02.190

Musayyib memperbanyak sholat karena meyakini bahwa Allah menjaga orang sholeh berikut tujuh keturunannya (Hafizh, 2010).

Usaha para ulama di atas memang benar. Anak-anak yang sholeh merupakan jawaban atas doa-doa orangtuanya. Islam sangat memperhatikan dasar-dasar pendidikan Islam sejak dini, sebagaimana yang dijelaskan Allah dalam surat Luqman ayat 13 :

Artinya: "Dan (ingatlah) ketika Luqman berkata kepada anaknya, di waktu ia memberi pelajaran kepadanya: "Hai anakku, janganlah kamu mempersekutukan Allah, Sesungguhnya mempersekutukan (Allah) adalah benar-benar kezaliman yang besar" (Departemen Agama, 2005).

Dari ayat diatas dapat dipetik pelajaran bahwa Luqman sebagai orangtua sangat memperhatikan pendidikan akidah sejak dini. Pendidikan ini menjadi dasar bagi anak sebelum ia menerima pendidikan ilmu pengetahuan. Dari sini mengapa dianjurkan untuk mengumandangkan adzan dan iqamah di telinga bayi yang baru lahir. Yaitu supaya kalimat pertama yang ia dengar merupakan kalimat-kalimat tauhid dan ajakan untuk beribadah. (Syam, 2019) menambahkan bahwa konsep parenting Luqman Hakim yang diberikan kepada anaknya merupakan konsep sederhana namun sulit dalam pengaplikasiannya. Bila konsep parenting ini diimplementasikan dalam kehidupan sehari-hari, anak akan memiliki karakter positif dalam keseharian. Mencetak generasi yang memiliki akidah yang kuat juga tidaklah mudah. Memerlukan kekompakan kedua orangtua dalam menanamkan akidah pada anak. Terdapat beberapa tahapan yang dapat dilakukan untuk menanamkan akidah yang kuat pada anak, yaitu:

a) Tahap pertama, yaitu pada saat sebelum menggauli istri. Hendaknya sholat sunah terlebih dulu dan dinatkan untuk mendapatkan anak yang sholeh dan sholehah.

b) Tahap kedua, yaitu pada saat anak berada di kandungan. Pada tahap ini, calon orangtua hendaknya memperbanyak membaca Al Quran, bersedekah, beristighfar, memperbanyak amal shaleh, dan menjauhi hal-hal yang dilarang agama. Walaupun anak masih berada dalam kandungan, akan tetapi ia sudah dapat merasakan apa yang dilakukan dan dipikirkan oleh orangtua.

c) Tahap ketiga, yaitu pada saat anak sudah lahir. Terdapat banyak hal yang harus dilakukan oleh orangtua pada tahap ini, antara lain:

1) Mengadzani bayi di telinga sebelah kanan dan mengiqomati di telinga sebelah kiri.

Copyright $\odot$ 2020, Universitas Muhammadiyah Metro| 29 
J-SANAK: Jurnal Kajian Anak

(p-ISSN: 2686-5343 |e-ISSN: 2715-7989)

Vol. (1) (2), (Januari - Juni) (2019), (Halaman)(15-34)

DOI: https://doi.org/10.24127/j-sanak.v1i02.190

2) Memperbanyak membaca Al Quran di telinga anak.

3) Memberikan teladan yang baik bagi anak.

4) Membiasakan anak untuk melaksanakan sholat sejak dini.

5) Mengajak anak untuk sholat berjamah di masjid sejak dini.

6) Menghibur anak ketika mereka berpuasa.

7) Menceritakan sejarah hidup para Nabi dan mengarahkan anak untuk meneladaninya.

(Susiba, 2019) menmabahkan bahwa upaya orang tua dalam memberikan pendidikan akidah untuk anak antara lain: menciptakan hubungan yang hangat dan harmonis dalam keluarga, menjalin komunikasi positif dengan anak, membiasakan mengucapkan kalimat thoyyibah, membudayakan sholat berjamaah dalam keluarga, mengenalkan sifat mulia Allah, kreatif dan terus belajar sejalan dengan perkembangan anak. Pola asuh demokratis juga dapat membentuk karakter baik pada anak, anak menjadi religius, dan memiliki kesadaran yang baik dalam setiap perilakunya (Fatkhurahman, 2016).

Orangtua yang telah menanamkan akidah pada anak sejak dini, maka akan memetik hasil yang baik pula. Terdapat beberapa manfaat yang dapat diambil dari penanaman akidah pada anak sejak dini, antara lain:

a) Memperkokoh keyakinan akan ke-Esaan Allah pada anak.

b) Membentuk kepribadian yang islami.

c) Menghindarkan anak dari hal-hal yang bersifat bid'ah dan khurafat (Musthafa, 2004).

I'anah (2017) menyampaikan bahwa berbuat baik kepada orang tua tidak berdiri sendiri dari anak kepada orang tua, melainkan relasi dua arah yang nantinya berpengaruh pada interaksi antara anak dengan orang tua. Beberapa pendapat di atas dapat dipahami bahwa kesholehan orangtua saja tidaklah cukup untuk membentuk anak yang berakidah kuat. Perlu adanya komitmen dan pendidikan yang berkesinambungan dalam mendidik anak. Supaya tujuan dari membentuk keluarga sakinah mawaddah warrahmah dapat tercapai.

\section{KESIMPULAN}

Setiap kejadian dan perilaku seseorang pasti terdapat sebab-sebab yang melatarbelakangi yang disebut dengan kausalitas. Adapun kriteria memilih calon pasangan hidup antara lain memilih seseorang yang baik agama dan akhlaknya, memilih calon yang sehat jasmani dan rohani, menghindari perkawinan dengan 
J-SANAK: Jurnal Kajian Anak

(p-ISSN: 2686-5343 le-ISSN: 2715-7989)

Vol. (1) (2), (Januari - Juni) (2019), (Halaman)(15-34)

DOI: https://doi.org/10.24127/j-sanak.v1i02.190

kerabat dekat, mengutamakan memilih calon istri yang masih perawan, memilih calon istri yang dapat menghasilkan keturunan, memilih calon suami yang bertanggung jawab, memilih calon suami yang menyayangi ibunya serta menyukai anak kecil.

Ajaran Islam mengijinkan perekayasaan genetika bagi suami istri yang tidak bisa mendapatkan keturunan secara alami. Dengan catatan sperma dan telur yang dibuahi berasal dari suami istri yang telah menikah. Selain itu, beberapa sifat yang dapat diturunkan dari orangtua biologis seperti ciri fisik, kecerdasan, gangguan mental, dan kepribadian seorang anak. Oleh karena itu, kondisi ibu ketika hamil merupakan kondisi yang sangat rawan. Setelah ibu melahirkan, hendaknya orangtua mulai menanamkan pendidikan akidah pada anak dengan mengadzani anak, membacakan Al Quran, dan mentalqin anak dengan kalimat tahlil.

\section{E. DAFTAR PUSTAKA}

Al-Albani, M. N., Saefullah, A., \& Sa'adiyatulharamain, K. (2002). Mukhtashar Shahih Bukhari. Pustaka Azzam.

Allingham-Hawkins, D. (2008). Successful genetic tests are predicated on clinical utility. MARY ANN LIEBERT, INC 140 HUGUENOT STREET, 3RD FL, NEW ROCHELLE, NY 10801 USA.

Alrabeeah, K., Wachter, A., Phillips, S., Cohen, B., Al-Hathal, N., \& Zini, A. (2015). Sperm retrieval outcomes with microdissection testicular sperm extraction (micro-TESE) in men with cryptozoospermia. Andrology, 3(3), 462-466.

Arikhman, N. (2016). TINJAUAN SOSIAL, ETIKA DAN HUKUM SURROGATE MOTHER DI INDONESIA. Jurnal Kesehatan Medika Saintika, 7(2), 140-151.

Arisman, A. (2018). Mahram dan Kawin Sesuku dalam Konteks Hukum Islam (Kajian Tematik Ayat-ayat Hukum Keluarga). JURIS (Jurnal Ilmiah Syariah), 17(1), 47-61.

Daudin, M. S. (1996). Hanya untuk suami. Gema Insani.

Departemen Agama, R. I. (2005). al-Quran dan Terjemahnya. Bandung: Diponegoro.

Fatkhurahman, M. (2016). Agama dan Ego Orang Tua (Telaah Kritis atas Spontanitas Anak dalam Pendidikan Keluarga). Cendekia: Jurnal Kependidikan Dan Kemasyarakatan, 14(2), 317-332.

Hafizh, M. N. A. (2010). Prophetic Parenting; caranabimendidikanak. Yogyakarta: Pro-U Media.

Halimah, M. (2018). Pandangan Aksiologi Terhadap Surrogate Mother. Jurnal Filsafat Indonesia, 1(2), 51-56.

Harahap, N. (2014). Penelitian Kepustakaan. Iqra': Jurnal Perpustakaan Dan

Copyright (C) 2020, Universitas Muhammadiyah Metro| 31 
J-SANAK: Jurnal Kajian Anak

(p-ISSN: 2686-5343 le-ISSN: 2715-7989)

Vol. (1) (2), (Januari - Juni) (2019), (Halaman)(15-34)

DOI: https://doi.org/10.24127/j-sanak.v1i02.190

Informasi, 8(1), 68-74.

Hastjarjo, T. D. (2011). Kausalitas menurut tradisi Donald Campbell. Buletin Psikologi, 19(1).

Hasyim, U. (1991). Anak Saleh (cara mendidik anak dalam Islam), bina ilmu. Surabaya.

Hermanto, A. (2017). Larangan Perkawinan Perspektif Fikih dan Relevansinya Dengan Hukum Perkawinan Di indonesia. Muslim Heritage, 2(1), 125-152.

Idris, M. (2019). Bayi Tabung Dalam Pandangan Islam. Al-'Adl, 12(1), 64-75.

Isnawan, F. (2019). PELAKSANAAN PROGRAM INSEMINASI BUATAN BAYI TABUNG MENURUT HUKUM ISLAM DAN HUKUM POSITIF INDONESIA. Fikri: Jurnal Kajian Agama, Sosial Dan Budaya, 4(2), 179200.

Kusramadhanty, M. (2019). Temperamen dan praktik pengasuhan orang tua menentukan perkembangan sosial emosi anak usia prasekolah. Persona: Jurnal Psikologi Indonesia, 8(2), 258-277.

Mussen, P. H., \& alih bahasa Tjndarasa, M. (1988). Perkembangan dan kepribadian anak (jilid 1).

Musthafa, F. (2004). Manhaj Pendidikan Anak Muslim. Jakarta: Mustaqim.

Pratiwi, D. S., Widiastuti, A. A., \& Rahardjo, M. M. (2018). Persepsi Orangtua terhadap Pendidikan Anak Usia Dini. Satya Widya, 34(1), 39-49.

Pustaka, B. (2002). Kamus Besar Bahasa Indonesia Edisi 3. Jakarta: Balai Pustaka.

Saiful, S. (2016). Bayi Tabung dan Inseminasi Buatan pada Manusia menurut Perspektif Hukum Islam. Pedagogik: Jurnal Ilmiah Pendidikan Dan Pembelajaran Fakultas Tarbiyah Universitas Muhammadiyah Aceh, 3(2).

Salehnur, S. (2014). Kausalitas. Jurnal Ushuluddin, 22(2), 224-238.

Santy, W. H., \& Irtanti, T. A. (2014). Pola asuh orang tua mempengaruhi temper tantrum pada anak usia 2-4 tahun di paud darun najah desa gading, jatirejo, mojokerto. Journal of Health Sciences, 7(1).

Setyowati, Y. D., Krisnatuti, D., \& Hastuti, D. (2017). Pengaruh kesiapan menjadi orang tua dan pola asuh psikososial terhadap perkembangan sosial anak. Jurnal Ilmu Keluarga \& Konsumen, 10(2), 95-106.

Supriyadi, B., \& Drajad, A. (n.d.). R Sumarjito, Yundaru Nurantini, dan Namastra Probosunu, 1992. Modul Biologi.

Susiba, S. (2019). PENDIDIKAN AKIDAH BAGI ANAK USIA DINI. POTENSIA: Jurnal Kependidikan Islam, 4(2), 155-168.

Syam, N. F. (2019). REVITALISASI PARENTING LUQMAN (USAHA PROGRESIF MEMBANGUN KETAHANAN NASIONAL MELALUI KELUARGA). Al-I'jaz: Jurnal Kewahyuan Islam, 5(2).

Syobromalisi, F. A. (2016). Kiat-kiat memilih pasangan menuju perkawinan bahagia.

Wiryantha, A. A. N. R. D., Suwitra, I. M., \& Sepud, I. M. (2017). Jurnal prasada. 4(1), 37-49. https://doi.org/10.22225/jhp.4.1.158.32-41

Copyright $\odot$ 2020, Universitas Muhammadiyah Metro| 32 
J-SANAK: Jurnal Kajian Anak (p-ISSN: 2686-5343 le-ISSN: 2715-7989)

Vol. (1) (2), (Januari - Juni) (2019), (Halaman)(15-34)

DOI: https://doi.org/10.24127/j-sanak.v1i02.190

Yusdiawati, Y. (2018). Penyakit Bawaan: Kajian Resiko Kesehatan Pada Perkawinan Sepupu. Jurnal Antropologi: Isu-Isu Sosial Budaya, 19(2), 8999.

Zahrowati, Z. (2018). Bayi Tabung (Fertilisasi In Vitro) Dengan Menggunakan Sperma Donor dan Rahim Sewaan (Surrogate Mother) dalam Perspektif Hukum Perdata. Halu Oleo Law Review, 1(2), 196-219.

Al-Albani, M. N., Saefullah, A., \& Sa'adiyatulharamain, K. (2002). Mukhtashar Shahih Bukhari. Pustaka Azzam.

Allingham-Hawkins, D. (2008). Successful genetic tests are predicated on clinical utility. MARY ANN LIEBERT, INC 140 HUGUENOT STREET, 3RD FL, NEW ROCHELLE, NY 10801 USA.

Alrabeeah, K., Wachter, A., Phillips, S., Cohen, B., Al-Hathal, N., \& Zini, A. (2015). Sperm retrieval outcomes with microdissection testicular sperm extraction (micro-TESE) in men with cryptozoospermia. Andrology, 3(3), $462-466$.

Arikhman, N. (2016). TINJAUAN SOSIAL, ETIKA DAN HUKUM SURROGATE MOTHER DI INDONESIA. Jurnal Kesehatan Medika Saintika, 7(2), 140-151.

Arisman, A. (2018). Mahram dan Kawin Sesuku dalam Konteks Hukum Islam (Kajian Tematik Ayat-ayat Hukum Keluarga). JURIS (Jurnal Ilmiah Syariah), 17(1), 47-61.

Daudin, M. S. (1996). Hanya untuk suami. Gema Insani.

Departemen Agama, R. I. (2005). al-Quran dan Terjemahnya. Bandung: Diponegoro.

Fatkhurahman, M. (2016). Agama dan Ego Orang Tua (Telaah Kritis atas Spontanitas Anak dalam Pendidikan Keluarga). Cendekia: Jurnal Kependidikan Dan Kemasyarakatan, 14(2), 317-332.

Hafizh, M. N. A. (2010). Prophetic Parenting; caranabimendidikanak. Yogyakarta: Pro-U Media.

Halimah, M. (2018). Pandangan Aksiologi Terhadap Surrogate Mother. Jurnal Filsafat Indonesia, 1(2), 51-56.

Harahap, N. (2014). Penelitian Kepustakaan. Iqra': Jurnal Perpustakaan Dan Informasi, 8(1), 68-74.

Hastjarjo, T. D. (2011). Kausalitas menurut tradisi Donald Campbell. Buletin Psikologi, 19(1).

Hasyim, U. (1991). Anak Saleh (cara mendidik anak dalam Islam), bina ilmu. Surabaya.

Hermanto, A. (2017). Larangan Perkawinan Perspektif Fikih dan Relevansinya Dengan Hukum Perkawinan Di indonesia. Muslim Heritage, 2(1), 125-152.

Idris, M. (2019). Bayi Tabung Dalam Pandangan Islam. Al-'Adl, 12(1), 64-75.

Isnawan, F. (2019). PELAKSANAAN PROGRAM INSEMINASI BUATAN BAYI TABUNG MENURUT HUKUM ISLAM DAN HUKUM POSITIF INDONESIA. Fikri: Jurnal Kajian Agama, Sosial Dan Budaya, 4(2), 179-

Copyright $\odot$ 2020, Universitas Muhammadiyah Metro| 33 
J-SANAK: Jurnal Kajian Anak

(p-ISSN: 2686-5343 le-ISSN: 2715-7989)

Vol. (1) (2), (Januari - Juni) (2019), (Halaman)(15-34)

DOI: https://doi.org/10.24127/j-sanak.v1i02.190

200.

Kusramadhanty, M. (2019). Temperamen dan praktik pengasuhan orang tua menentukan perkembangan sosial emosi anak usia prasekolah. Persona: Jurnal Psikologi Indonesia, 8(2), 258-277.

Mussen, P. H., \& alih bahasa Tjndarasa, M. (1988). Perkembangan dan kepribadian anak (jilid 1).

Musthafa, F. (2004). Manhaj Pendidikan Anak Muslim. Jakarta: Mustaqim.

Pratiwi, D. S., Widiastuti, A. A., \& Rahardjo, M. M. (2018). Persepsi Orangtua terhadap Pendidikan Anak Usia Dini. Satya Widya, 34(1), 39-49.

Pustaka, B. (2002). Kamus Besar Bahasa Indonesia Edisi 3. Jakarta: Balai Pustaka.

Saiful, S. (2016). Bayi Tabung dan Inseminasi Buatan pada Manusia menurut Perspektif Hukum Islam. Pedagogik: Jurnal Ilmiah Pendidikan Dan Pembelajaran Fakultas Tarbiyah Universitas Muhammadiyah Aceh, 3(2).

Salehnur, S. (2014). Kausalitas. Jurnal Ushuluddin, 22(2), 224-238.

Santy, W. H., \& Irtanti, T. A. (2014). Pola asuh orang tua mempengaruhi temper tantrum pada anak usia 2-4 tahun di paud darun najah desa gading, jatirejo, mojokerto. Journal of Health Sciences, 7(1).

Setyowati, Y. D., Krisnatuti, D., \& Hastuti, D. (2017). Pengaruh kesiapan menjadi orang tua dan pola asuh psikososial terhadap perkembangan sosial anak. Jurnal Ilmu Keluarga \& Konsumen, 10(2), 95-106.

Supriyadi, B., \& Drajad, A. (n.d.). R Sumariito, Yundaru Nurantini, dan Namastra Probosunu, 1992. Modul Biologi.

Susiba, S. (2019). PENDIDIKAN AKIDAH BAGI ANAK USIA DINI. POTENSIA: Jurnal Kependidikan Islam, 4(2), 155-168.

Syam, N. F. (2019). REVITALISASI PARENTING LUQMAN (USAHA PROGRESIF MEMBANGUN KETAHANAN NASIONAL MELALUI KELUARGA). Al-I'jaz: Jurnal Kewahyuan Islam, 5(2).

Syobromalisi, F. A. (2016). Kiat-kiat memilih pasangan menuju perkawinan bahagia.

Wiryantha, A. A. N. R. D., Suwitra, I. M., \& Sepud, I. M. (2017). Jurnal prasada. 4(1), 37-49. https://doi.org/10.22225/jhp.4.1.158.32-41

Yusdiawati, Y. (2018). Penyakit Bawaan: Kajian Resiko Kesehatan Pada Perkawinan Sepupu. Jurnal Antropologi: Isu-Isu Sosial Budaya, 19(2), 8999.

Zahrowati, Z. (2018). Bayi Tabung (Fertilisasi In Vitro) Dengan Menggunakan Sperma Donor dan Rahim Sewaan (Surrogate Mother) dalam Perspektif Hukum Perdata. Halu Oleo Law Review, 1(2), 196-219. 